\title{
Gender inequalities in transnational academic mobility and the ideal type of an academic entrepreneur
}

\author{
Regula Julia Leemann
}

Educational Sociology, School for Teacher Education, University of Applied Sciences Northwestern Switzerland, Basel, Switzerland

\begin{abstract}
Based on a study on academic career paths of $\mathrm{PhD}$ graduates in Switzerland this paper is concerned with the individual and institutional factors that affect transnational academic mobility in the postdoctoral period. It will be argued that the institutionalization of geographic mobility in academic career paths through research funding institutions and universities have gendering and stratifying effects. Complex formations related to gender, partnership, children and dual career constellations, as well as to social class and academic integration are resulting in inequalities in the accumulation of international cultural and social capital.
\end{abstract}

Keywords: geographic mobility, academic mobility, transnational mobility, academic career, gender, social origin, dual career, gender, family ties

This is an electronic version of the accepted article published in

Leemann, Regula Julia (2010). Gender inequalities in transnational academic mobility and the ideal type of academic entrepreneur?, in: Discourse: Studies in the Cultural Politics of Education, 31(5): S. 605 - 625.

The Journal Discourse: Studies in the Cultural Politics of Education is available online at:

http://www.tandfonline.com/doi/pdf/10.1080/01596306.2010.516942

Corresponding Author

Prof. Dr. Regula Julia Leemann

Professur Bildungssoziologie

Pädagogische Hochschule n/w Basel

Clarastrasse 57

$\mathrm{CH}-4058$ Basel

phone: *41 (0)616901916

fax: *41 (0)616901990

regula.leemann@fhnw.ch

www.bildungssoziologie.ch 


\section{Introduction}

Despite having achieved a significant improvement in the equality of men and women in academic life over the last decades, in all European countries and beyond women are having difficulties getting ahead in research careers (European Commission 2009). The aim of this paper is to contribute to the discussion of possible reasons for the under-representation of female academics at higher career levels by focusing on an up until now rather unlit topic: the demand to be geographically mobile while pursuing an academic career. For this purpose I will tackle the question how the demand to be readily mobile and to gather research experience at a research institution abroad has different implications for female and male careers and how social conditions and constraints like partnership, family and dual-career constellation shape transnational academic mobility of young researchers in gender-specific ways and which additional factors like social origin, academic integration or social origin influence the opportunities to be mobile.

In answering these questions I will refer to data of young researchers pursuing an academic career gathered in the context of a study commissioned by the Swiss National Science Foundation (SNSF) to investigate the main reasons for the disproportionate loss of women from the academic career path (metaphorically termed the 'leaky pipeline') and the role of the SNSF for dis(integration) of female academics (Leemann \& Stutz, 2008).

Most of the young academics are scientists who graduated some years ago inside of the Swiss university system with a PhD. Some of them were already geographically mobile in earlier career steps, i.e. they came to Switzerland from abroad to start a $\mathrm{PhD}$ at a Swiss university. A great deal of the respondents went for a stay abroad after their PhD. 
After a short description of the design of the study I will give an overview on the prevalence of transnational academic mobility in the Swiss university sector and embed the topic of mobility in the context of Swiss academic institutions (SNSF, universities) and their funding and recruiting policies. Thereby I will argue that transnational academic mobility is institutionalised in academic career paths and I will draw attention to the beliefs of quality and excellence that are implied with internationality. Following a literature review on socially and gendered structured patterns in transnational academic mobility I will demonstrate, on the basis of the quantitative data analysis, which type of individual meets the required willingness or capacity to leave his or her home affiliation and to move to another country in order to gather research experiences abroad. In the last section, four constellations of mobility patterns are presented that give an insight in the complex picture of social conditions and constraints structuring the mobility patterns of academics.

\section{Design of the study}

The arguments and results presented in this paper are based on a study on 'Gender and Research Funding' in Switzerland, carried out from 2006 to 2008 (Leemann \& Stutz, 2008). On the one hand, we gathered and analyzed quantitative data on the academic pathways of young scientists; on the other hand, we conducted in-depth interviews with upcoming researchers on their academic career trajectories.

\section{The survey of 2002 doctoral graduates (panel 2003/2007)}

With panel data from the Swiss Graduates Survey regularly carried out by the Swiss Federal Statistical Office I was able to examine which individual and institutional factors influence academic geographic mobility in the postdoctoral period. In this 
Survey, all university graduates awarded a doctorate in $2002^{1}$ were questioned in 2003 and again in 2007 by the Federal Statistical Office on their career development, family situation, social background and other socio-economic factors. In the wave of 2007 I had the opportunity to insert a supplementary module on selected topics of academic career. $^{2}$

Compared to the initial population of $\mathrm{PhD}$ graduates in $2002(\mathrm{~N}=1689)$, there were 538 people in the second wave with valid entries for both surveys, which yields a total response rate of $31.9 \%$. Since not all of the people who were surveyed filled out a particular module on academic career in the context of our ongoing study, the available number of observations for the analyses comes down to 470 people (total response rate: $27.8 \%$ ).

\section{b) Interviews with young researchers from different disciplines}

In addition, we conducted 30 in-depth interviews with a selected group of researchers who graduated with a $\mathrm{PhD}$ in 2002 and 15 in-depth interviews with researchers who had submitted their first application for a research funding to the SNSF between 2002 and 2006. The aim of the interviews was to evaluate subjective experiences, motivations, and reasons for undertaking academic career paths, or for leaving the academic/university sector. The interviews were carried out across Switzerland (via personal interviews) and abroad (via telephone interviews). The interviewees were

\footnotetext{
$1 \quad$ With the exception of a) the University of St. Gallen and the University of Basel, which did not supply the addresses of doctoral graduates, and b) the area "medicine and pharmacy", which contributed only a few isolated subjects as the graduates were only included if they passed the state examination at the same time (due to the different significance attributed to the doctorate in medicine). 2 The questionnaires are available online: http://www.bfs.admin.ch/bfs/portal/de/index/infothek/erhebungen_quellen/blank/blank/bha/02.html (accessed 30 November, 2009).
} 
chosen to reflect as broad and comprehensive an image as possible of the various career and private life (family) realities in the different disciplines.

\section{Transnational academic mobility: from the Swiss perspective}

To achieve the ambitious goals of the Lisbon strategy, a whole number of initiatives have been launched at European level over the last couples of years in order to improve the framework conditions for researchers in Europe and to provide them with better career prospects. As mobility has become an indispensable element in the career trajectory especially of early career researchers a variety of activities and attempts aim to establish better conditions for geographic mobility (Gabaldon et al., 2005; van der Hijden, 2009). The Swiss Higher Education System and Research Area are influenced by these attempts and developments to establish a European Research Area and to attract highly qualified researchers even though, as a non-EU Member State, Switzerland's collaboration with the European Union is based only on bilateral agreements. $^{3}$

In Switzerland, inward and outward geographic mobility is an important structural condition of the university sector. Compared with e.g. the UK, Italy, France or Germany, and particularly compared with the USA, - it has a particularly mobile population (Bekhradnia \& Sastry, 2005, p. 9). The statistics of the OECD illustrate that inside of Europe the highest rate of foreign students on the doctoral level (44\%) is to be found in Switzerland (OECD, 2008, p. 366). The statistical data of the personnel at Swiss universities underpin the result of high incoming mobility also at professorial level. In 2008, 45\% of all professors were foreign academics, in some universities this proportion amounts to 60 or $70 \% .{ }^{1}$ Our own data illustrate that the academic influx of

\footnotetext{
3 See Contact Office for European Research Innovation and Education http://www.swisscore.org/E/switzerland/Pages/default.aspx.
} 
emerging researchers from abroad has radically increased since the 1990s (Leemann $\&$ Stutz, 2008). As to outgoing mobility, more than $40 \%$ of the $\mathrm{PhD}$ graduates who remain after graduation in the university sector spent a research period abroad within five years after the $\mathrm{PhD}$.

In Switzerland there are no alternatives to supporting one's research career through the Swiss National Science Foundation (SNSF). The SNSF pushes, enables and fosters mobility. Going abroad with a fellowship from the SNSF helps building up international networks and leads to academic recognition and credibility (Leemann, Dubach \& Boes, 2010). The guidelines and regulations of the SNSF clearly demand that all young academics pursuing an academic career undertake a stay abroad of at least one-year duration. Accordingly, its instruments of individual funding are either linked with spending a period at a research institution abroad ${ }^{4}$, or they support academics after a stay abroad in returning into the Swiss University System and they like to attract foreign academics to carry out research work in Switzerland ${ }^{5}$.

This policy is linked with the recruitment strategies of the Universities. Currently getting a permanent position at a Swiss university requires in most cases research experiences abroad, either in the form of being a foreign researcher with research training and employment in another country before immigration to Switzerland (incoming mobility) or in the form of research experiences abroad typically after the $\mathrm{PhD}$ (outgoing and returning). All in all, inside of the Swiss University System we find norms, rules, beliefs, and conventions on 'internationality' and 'transnational academic mobility' with a nexus to notions of excellence and quality that guide the strategies and decisions of research funding institutions and universities as well as the plans and blueprints of young scientists.

\footnotetext{
$4 \quad$ e.g. http://www.snf.ch/E/funding/individuals/advancedresearchers/Pages/default.aspx.

5 e.g. http://www.snf.ch/E/funding/individuals/ambizione/Pages/default.aspx.
} 


\section{Gender, partnership and family: Patterns in transnational academic mobility}

In the last two decades a few research studies on the phenomenon of academic mobility have considered the gender, partnership, dual-career, and life-course dynamics in mobility patterns. These approaches are an advance on earlier research that was informed by an individualistic male bread winner model. In order to conceptualise the gendered dimension of reconciling family and academic career I draw on the analytic framework of 'linked or coupled lives' by Krüger and Levy (2001). The authors point out that different dimensions of institutionalisation of life courses have to be taken into account to capture the full complexity of life courses:

(a) Besides a sequential institutionalisation of the life course (education, paid work, retirement) aspects of simultaneous social participation of the individuals are relevant in structuring career paths whereby the most important characteristic is the simultaneity of family and occupational participation.

(b) Family life ties together the life courses of individual family members: Therefore life courses cannot be fully understood as individual trajectories only. "They have to be seen as coupled or linked among each other" (Krüger and Levy, 2001, p. 161) and are not individual projects but projects of family members and partners.

(c) A further institutional force that moulds life courses is adjacent institutionalisation. Modern societies are differentiated in several subsystems and organisations (shops, public transport, labour market, schools, ...) which put constraints on a family's working and structure the arrangement of labour division and career decisions of the partners by their organisational arrangements and demands (opening hours, costs, accessibility, time schedules, degree and security of financial support). 
(d) Gender as a master status structures the life course unequally for men and women. The notion of male and female master status encompasses the perspective of "doing gender" by culturally oriented actors through their everyday performances on the micro-level as well as by various forms of social institutionalisation on the mesolevel (e.g. family and division of labour). Gender as a central feature of the social structure is responsible for the gender specific complementary and interdependent constructions of academic path ways inclusive academic mobility patterns.

To illustrate the mobility patterns of young academics on the basis of a short review of the literature I will differentiate in the following analytically three dimensions and look at them separately: Gender, linked lives and tied migration, family and children.

\section{Gender}

Women academics have been shown to be less geographically mobile than their male counterparts. This result holds for older studies (e.g. Marwell, Rosenfeld \& Spilerman, 1979; Rosenfeld \& Jones, 1987) as well as for more recent studies (e.g. Moguérou, 2004). Geographic constraints on the career mobility of academic women have a decisive influence on their career advancements. Greater geographic immobility can put women at a disadvantage with regard to getting tenured positions (Kulis \& Sicotte, 2002; Rosenfeld \& Jones, 1987) and can be understood as one of the key factors for the 'leakage' of the academic pipeline and for the under-representation of female faculty in academia (Ackers, 2004; McBrier, 2003).

\section{Linked lives - tied migration}

Women academics are more likely than men to be married to other scientists and to deal with the special situation of a dual science career where two academics have to attune their career plans to each others' (Marwell et al., 1979; Rusconi \& Solga, 2007; 
Shauman \& Xie, 1996). As a survey of young French $\mathrm{PhD}$ graduates shows married women - compared with their unmarried counterparts - are less internationally mobile during their postdoc phase, especially when the United States are the destination. For married men there were no similar effects (Moguérou, 2004). We can conclude that living in a stable partnership is a mobility barrier for female academics but not at all costly for male scientists.

Research that focus on the dynamics between the two partners when it comes to the situation that one partner should or could move to another place underpins this result. Compared to male academics female scientists more frequently follow their partners to another city or country (Bronstein, 2001; Ledin, Bornmann, Gallon \& Wallon, 2007). In addition male scientists often report that their wives had followed them as a consequence of their changing jobs while this is rarely the case for female academics (Romanin \& Over, 1993). Traditional gender roles are still prevalent and independently of the educational and professional status of the spouse her mobility is more 'tied' to that of their male partner than vice versa (Ackers, 2004). In contrast to these results, the migration rates of doctoral scientists in the study of Shauman and Xie (1996) do not show any difference between dual-career couples, one-career couples, or unmarried scientists. This is the case for both women and for men but was affected by the occurrence and age of children. We can assume that as long as there are no children (planned) it is easier for a dual-career couple to find ways of managing partnership at a distance (Ackers, 2004).

\section{Starting a family: Children}

With the arrival of children the professional situation and career plans of a couple gets more complicated. The analysis of Romanin and Over (1993) of around 300 Australian academics indicate that the probability of going abroad for academic 
qualification is lower for academic mothers and fathers. The study of Teevan, Pepper and Pellizzari (1992) on the reasons that academics accept or reject offers of faculty positions indicates that family needs, including dual-career relationships are a major consideration for both men and women.

The empirical findings of a broad data set of doctoral scientists in the US portray, in contrast, that the effects of children on female academic mobility are much more pronounced than the effects on male academics (Shauman \& Xie, 1996). Particularly in the first generations of female scholars family obligations often limited their geographic mobility (Bronstein, 2001).

\section{Transnational capital}

To understand the implications of gender specific academic mobility for the unequal integration of women and men into the scientific community I will refer to Bourdieu's concepts of social, cultural and symbolic capital (Bourdieu 2004 [1986]). Bourdieu defines social capital as ,the aggregate of the actual or potential resources which are linked to the possession of a durable network of more or less institutionalised relationships of mutual acquaintance and recognition" (Bourdieu 2004 [1986], 21). In the meantime, transnational social capital i.e. contacts and cooperation with researchers around the world is becoming ever more important in academia. It is built up by personal contacts to (prospective) relevant partners in the context of daily work, during qualification periods, while attending congresses, in research cooperation and through periods spent abroad.

Its accumulated work gives access to other forms of capital and is able to be transformed into cultural capital (publications, internationally oriented habitus, language skills) and symbolic capital (reputation, credit, power) that are relevant for establishing in academia. If academics are not involved in these processes of 
accumulation and transformation of social capital, they get marginalized. Eventually, they are placed on the edge of the academic field and fall out of the game (Leemann and Da Rin 2010).

\section{The ideal type of an academic entrepreneur}

To what extent are transnational career moves of female and male researchers affected by individual characteristics and institutional conditions? On the basis of the above mentioned panel data set, I calculated a model to explain the probability that an upcoming researcher spent at least one research period abroad in the five year period after $\mathrm{PhD}$ graduation (see table 1).

Besides a range of sociodemographic variables (such as gender, age, previous geographic mobility, social origin, partnering and parenting), the multivariate analyses include the subject area and the region of the university of $\mathrm{PhD}$ graduation. In order to measure long-term effects of scientific integration on academic mobility, I use information gathered in the first wave of the panel survey: position as an assistant, the participation in a postgraduate programme and/or in a mentoring programme, and subject-specific and career-oriented support. Furthermore, I take into account whether the respondent got support by research funding (in minimum one fellowship or one project funding approved, in minimum one project participation as junior scientist since Master's graduation).

The analyses are weighted in order to obtain results for the initial population of doctoral graduates. The weighting factor provided by the Swiss Federal Statistical Office indicates the inverse probability that a particular observation based on the sampling design will be contained in the sample. All calculations are carried out in Stata (version 10). 


\section{How to read the table}

The asterisk in column 2 indicates that the specific variable has a verifiable influence on academic mobility. The level of statistical significance is indicated by one asterisk (*) (remarkable influence), by two asterisks $(* *)$ (significant influence Einfluss) and by three asterisk $(* * *)$ (high significant influence). To know if this influence is positive or negative we have to check the odds ratios (third column).

An odds ratios greater than one represents an increase in the likelihood of having spent a research period relative to not having spent a research period - in other words the specific variable has a positive influence on academic mobility -, whereas an odds-ratio less than one represents a decrease in the likelihood of having spent a research period relative to not having spent a research period.

For example if a young scientist lives in a partnership one year after the $\mathrm{PhD}$ graduation (variable "domestic partnership") the likelihood of a stay abroad in the following postdoctoral period is 0.4 . This means that the probability is much smaller (4:10, less than half) compared to a scientist who is single.

\section{Results}

Our main result is that female academics have the same chance of having spent a research period abroad when they are compared with their male counterparts. Gender is not significant. In contrast, the other socio-demographic factors show a significant positive or negative influence on academic mobility. The older the academics are, the less mobile they become. The probability to go abroad reduces with each age year. As other studies indicate, older graduates are less able or willing to go abroad during their postdoctoral phase (Rosenfeld \& Jones, 1987; Shauman \& Xie, 1996). They are probably more settled into an area, continue a previously begun career or get less support by supervisors and mentors in planning a postdoc abroad. 
Former geographic mobility (researchers with a Master's degree from abroad) fosters mobility in the postdoctoral period. The likelihood is nearly three times higher when we compare with young researchers who grew up in the Swiss University system. We can assume that the previous experience of mobility helps and motivates them being mobile in later career stages. Having a mother with a university degree ${ }^{2}$ strongly affects outgoing mobility. Familiarity with the milieu of academia has a decisive positive influence on moulding an academic habitus (Bourdieu, 1990; Bourdieu \& Passeron, 1971). which in these days has to signal a commitment to internationality. When coming from an academic family, emerging researchers are possibly more aware of the importance of spending a period abroad, and they tend to be more willing to take on all of its intricacies and uncertainties.

Our analysis substantiates that the birth of children after the doctorate as well as a stable partnership impedes mobility abroad. Additional analyses (not shown in the table) reveal that these results hold for women as well as for men. Planning a period abroad with children and partner is complex. Childcare has to be organised and suitable employment must be found for the partner; both partners must have realistic options on their return home; the entire organisation of mobility requires adequate financial resources. However, the effect of children must not be interpreted as unidirectional; rather, it can be additionally assumed that whoever plans to go abroad for a research period, or is already abroad, tends to postpone the decision to have children. 
Table 1: Determinants of a research period abroad within five years after the doctorate

Socio-demographic factors

Woman

Age

Masters Degree abroad

Father university degree

Mother university degree

Domestic partnership (one year after the doctorate)

Birth of child within five years after the doctorate

University factors

French-speaking part of Switzerland

Subject area $(\text { natural sciences }=\text { base })^{3}$

Social sciences and humanities

Economics

Medicine/pharmacy

Technical sciences

Integration during the doctorate

Position as assistant

Participation in a postgraduate program

Mentoring programme during doctorate ${ }^{4}$

Subject-specific support during doctorate

Career-oriented support during doctorate

Support by research funding ${ }^{5}$

Fellowship from SNSF approved

Fellowship from other institution approved

Project funding from other institution approved

Project participation SNSF funded b

$-0.659$

(0.536)

$-0.199 * * *$

(0.077)

$1.075 * *$

(0.447)

$-0.182$

(0.503)

$1.355 * *$

(0.600)

$-0.952 * *$

(0.478)

$-0.896^{*}$

(0.525)

0.303

(0.434)

$-0.801$

(0.796)

0.857

(0.814)

$-0.942$

(1.123)

$-0.409$

(0.470)

$-0.653$

(1.248)

$2.402 *$

(1.404)

0.155

(0.152)

$0.673 * *$

(0.328)

11.0

$2.518^{* * *}$

(0.510)

0.138

(0.669)

$0.893 *$

$(0.498)$

0.802
0.4

Odds ratios

0.8

0.4 
Project participation funded by other institution

$1.967 * * *$

\section{Constant}

Number of observations

Value of the log-likelihood

Model Chi-squared

Degrees of freedom

Source: Swiss Graduate Survey (Swiss Federal Statistical Office), own calculations Note: Logistic regression model. Effect coefficient (b), Standard errors in parentheses. $* \mathrm{p} \leq 0.10, \quad * * \mathrm{p} \leq 0.05, \quad * * * \mathrm{p} \leq 0.01$

Two variables that measure the degree and forms of integration during doctoral study show a significant influence. Those academics who attended mentoring-programmes and who received career-specific support (from their doctoral supervisor, from other academics or from particular courses) were geographically more mobile in the five years after completing the doctorate. Being mentored in the context of geographic mobility means that a young scientist gets support by an established academic who fosters transnational mobility, is willing to write a letter of recommendation or to make a phone call in order to establish an important contact abroad and who offers or points to opportunities to come back after the completion of the postdoc.

Support from research funding institutions also stands in a positive relation to spending a period abroad. The SNF fellowships connected to mobility requirements are particularly important, as are research applications and research participation in projects which are financed by other organisations (which can be presumed in part to be located abroad).

To put these results in a nutshell: The researcher with most probability of being mobile is a young scientist from abroad (i.e. who was already mobile in former stages of his or her career), with an academic family background, without children and partner, who had career-oriented support during doctoral studies (i.e. is well 
integrated into the academic field) and got an approved fellowship from the SNSF or was funded by another research funding institution.

Kenway and Fahey (2007), Pongratz and Voß (2003) and Schultheis (2007) indicate that the ideal type of an academic entrepreneur is nomadic and monadic, is de-territorialised, disembodied and dis-embedded. To elaborate on their arguments, this ideal type is an independent, socially privileged, academically supported cosmopolitan academic individual. This academic can readily engage in transnational mobility for career purpose and without difficulties and obstacles can confidently settle into new living situations.

\section{Different types of academic entrepreneurs}

However, the spectrum of lifestyles amongst the academics I interviewed shows above all that this ideal is an ideological or normative construction, which masks the social conditions of possibility behind the norm (Schultheis, 2007). The picture that I can draw from the interviews substantiates the idea that the plans, strategies and career decisions of emerging researchers are structured by their economic, social and academic situation and by their rootedness in a network of family (original family as well as one's own family), domestic partnership, friendships and local familiarities.

Class and gender inequalities can gain ground, since career support by mentors and doctoral supervisors, basic integration in international academic networks or support from the partner and one's family of origin is fundamental to planning and undertaking a period abroad. Considering for example the likelihood of being mentored by a university professor, we observed in our study that female upcoming researchers have a significantly smaller chance - less than half of the chance of male researchers - of finding a professor in the postdoc phase who will rigorously support and foster them in a mentoring relationship (Leemann, Boes \& Da Rin, 2009). 
Additionally, we found that young female researchers have significantly fewer academic contacts with professors and peers abroad, another barrier to being internationally mobile (Leemann, Dubach \& Boes, 2010). Research on institutional values and norms in the university sector still points to various gender inequalities in academia which are deeply rooted in the academic culture itself, its symbolic practices, and career constructions (e.g., Krais, 2002; Simienska \& Zimmer, 2007). Moreover, with regard to the topic of reconciling family and academic career, there was strong evidence in our study that male academics get support by their partner when it comes to starting a family but not the other way round. Neither do the partners of the female academics reduce their employment to part time nor do they take over relevant child care duties as it is the case with male academics becoming a father. As a consequence female academics forego having children (Leemann, Boes \& Da Rin, 2009).

Academics are not monads or nomads without connections or roots, and their lives need to be analysed as 'linked or coupled lives' in the context of the formative institutional forces of (heterosexual) domestic partnership, family and gender and with regard to the fact that life courses are not individual projects but one of family members and partners (Krüger \& Levy, 2001).

With regard to the topic of academic mobility, we found up to now four different mobility patterns or constellations of academic entrepreneurs in our data that are to be understood more as 'analytical' dimensions in comprehending mobility than as real forms (in the sense of pure types):

(1) Flexible academic entrepreneurs 'without obstacles to mobility set by domestic partnership and family'.

(2) Flexible academic entrepreneurs who 'put all their eggs in one basket'.

(3) Dual career academic entrepreneurship, as 'the impossible thing'.

(4) Inflexible academic entrepreneurs, 'not without domestic partnership and family'. 
All four forms are fundamentally conceivable for women as well as for men. The constellations are being found in mixed forms, and in the course of a career they can change.

With constellation 1, it is often the case that the partner - and any childrenalso go(es) abroad and that the partner subordinates her/his own career to that of the interviewee as it is the case in the following example. This Swiss academic has just got a permanent position as a lecturer in humanities at a university in Great Britain and will soon leave his home university. His partner who lags in her career some steps behind his career will follow him some months later.

She will come with me next spring. At the moment, she has still an appointment here at the University, which will run out with, or would run out with time. And there, there will be probably certain opportunities, so not a permanent position, but a bit of teaching, and by then, she will have finished her PhD and think about if and how she will go on in academia.

When I asked him if he made any relevant considerations in planning his professional or private life course he denied:

No, as I said earlier, I am not a big planner who is planning ten years in advance. One thing arises out of another thing. This holds for my private life as well as for my academic career.

He disapproves the idea that he could have planned or had to plan his private or professional career and instead demonstrates his flexibility for career purpose.

Thereby, he does not take into account that he can pursue his career without foregoing the closeness to his partner or adapting his career to her career plans.

In our sample we had also female academics with partners whose careers lag some steps behind hers. It seems that this situation is a kind of relieving factor when it comes to attuning two careers and being geographically mobile. In the following I will depict the example of a female academic. She and her partner have currently three children. After several years of research of her abroad the family is now back in Switzerland. She holds a position as a junior professor in mathematics while he is finishing his studies in humanities. She stresses that only due to the flexibility of her 
partner who was willing to interrupt his own studies in Switzerland and care for the children she had been able to meeting the demands of being geographically mobile. "If my husband not had been so flexible, we would not have been able to do that".

In contrast to the above mentioned academic from the humanities her career trajectory seems to be based on a straight plan. Several times she points out that a life with three children, stays abroad, career demands and a partner could not be mastered without a detailed and long-dated planning. We can assume that academic mothers are more under pressure to care about mapping options and arrangements and finding compromises that are conceivable for the whole family.

Scientists within constellation 2 either plan to start a family later or forego children, are doing without a partner (for the moment), or the family/partner stays behind, creating a situation of 'living apart together', in which the interviewee does not bear family responsibilities.

The rules relative to geographic mobility and academic career are put in a nutshell by one of our male interviewees. "If somebody will be successful he has to put all his eggs in one basket". In this basket there is no space for a private life, for family and children. This comes second.

The following example shows nicely how this norm shapes the decisions and life form of this academic. He is married and has a pre-school aged child. Recently he got a full professorship in Germany. His wife together with the child still lives in a city in Switzerland where she has a qualified part time job. During the week he is in Germany, at weekends he moves to his family home. He hopes that in a few years he will find another position at a university that is placed nearer to his family home. His objective is to see his family at least once during the week. 
There is no doubt in his narratives that an academic has to be ready to be mobile and to go abroad. "One has to move". Answering to the question if he made any private or professional compromises with regard to his career he reckoned:

Yes, I think that the compromise was at family's cost whereby I did not have the option to make a choice. The situation was that my job as an assistant in [CITY IN SWITZERLAND] run out and at this moment I got the position in [CITY IN GERMANY]. It was not possible to defeat this position. In academia it is not possible to defeat such an opportunity at this career stage because you would be labelled in future applications!

This model of 'living apart together' where the mother bears the brunt of child care allows him pursuing his academic career. Even it is not a traditional one it is still built on a gendered structure of responsibilities in work and family life that allows the male partner to put his shirt on the career.

Constellation 3 is marked by approaches toward, attempts at and considerations about a dual-career entrepreneurship, but at the same time witnesses its impossibilities and difficulties, such as broken relationships or the impossibility of planning two uncertain careers together.

One of my interviewee is an outstanding female physicist who was geographically very mobile during her doctoral and postdoctoral studies. At the age of 35 she got her first permanent position in Switzerland and is now a professor in Germany. She is single and childless. When I asked her about her experiences and difficulties in reconciling private and professional life, she answered:

Presumably, it would have been difficult to be married or generally to live in a stable and long lasting partnership because I lived at so many different places. I had a partner for many years but later, unfortunately the relationship broke down. I think what was contributing to this disruption was the fact that both of us worked at different places and only for short periods. Most of these postdoc fellowships are for a year or two and then you have to move. For sure, this had some effects. The alternative would have been to say: OK, I put my career on the back burner and I follow my partner. Or I require that my partner follows me and looks for a job near by. This would have had the consequence that the respective partner wouldn't have been able to continue in his or her specialist area.

As we can see this physicist encountered similar difficulties to reconcile a life in partnership with strong demands of being internationally mobile in her discipline and 
of looking for an permanent position anywhere in a globalised world. She too put all her eggs in one basket as it is the case in constellation 2 and did not make any compromises like attuning her career to the career steps of her partner who was also a globally mobile academic. But in contrast to constellation 2 she had to take the loss of her partnership.

Another 'possibility' to deal with the impossibility of managing two careers, a family and the required mobility is to relinquish the research career path as one of our interviewed physician had done. He stressed that it is nearly impossible to find a qualified job with career options for him and his partner at the same place.

It is not the case that the children would bother. It is the "at-the-same-place". Children you can organise. (...) So children are not as bad as the guide-line that both partners wish to live together at the same place, or that they find at the same time a job within commuting distance which is suitable and with options for climbing up the career ladder. This is impossible.

In his case he decided to stay in Switzerland and to bank on a clinical career knowing that without investments in research sooner or later he will drop out of the university sector. What is striking in his statement is the assumption that the existence of children is only a problem of organisation. None of our academic mothers drew a similar picture. In contrast they talked about all the problems they had or they would have to solve while going abroad for a research period. This leads us to the next constellation.

Constellation 4 characterises those academics who are not prepared to forego social integration. They adjust their mobility plans, undertake mobility in a limited form or forego academic mobility altogether.

And this was difficult even for me, because my husband, he was here [in Switzerland] because he has his own [self-employed business]. He was not able - for that reason I went to UK and not to the USA. Those are compromises, which one makes, which one makes willingly. We simply flew each week-end to and from. It was a strenuous time, but a good time too.

In the case of the above quoted female physician, the SNSF suggested she spend her postdoc at an outstanding research institute in the USA. As her husband was not 
willing or able to accompany her, she decided to go to an institute in the UK that was less outstanding in her research field in order to see her partner regularly. This example points to two important facts: On the one hand, female academics show initially the demanded academic mobility: they were academically mobile as often as male academics (see table 1). Only at a closer look we can find small but important differences in the mobility patterns of women and men that lead in the long term to unequal amounts of social, cultural and symbolic capital. In this example we can assume that at the institute in the USA she would have met a better academic context and community for her research career as it was the case with the institute in the UK. On the other hand, economic capital plays an important role in academic mobility. The financial support by research funding institutions allows a researcher to go abroad but not to be mobile in the sense of a cosmopolitan traveller with different roots and homes. Financial support by a professionally well established partner or by one's family of origin is the prerequisite.

These different constellations have different consequences for the shape of the private lives and the professional trajectories of academics and their partners. They tend to correspond more to a 'male' or more to a 'female' pattern or they carry gender specific peculiarities. For example constellation 1 is more available and open to men and allows them to better connect an academic career with geographical mobility, without having to give up the social connection of a domestic partnership or starting a family in the long run. Women, by contrast, face a dilemma, according to our surveys, since they cannot count on a partner who would support their flexibility by fitting his career trajectory to the demands of her academic career and who would play a central role in the (organising of) childcare, taking over the responsibilities and investing the time (Leemann, Boes \& Da Rin, 2009). Therefore women are more likely to be found 
in the situation of constellation 4. In situations where they represent constellation 2 or 3 they are academically successful but renounced children and partnership in the long run. This can explain the higher rate of female academics without children in academia when we compare with male academics.

\section{Conclusion}

Internationality has become a strong requirement in the academic sector and transnational academic mobility is an indispensable element in the career trajectories of upcoming researchers. The requirement of being geographically mobile is bound up with various objectives. The norm of having worked for a certain period at a research institution abroad in the course of gaining academic qualifications can functionally and disciplinarily be justified. Nevertheless it also contributes to socialising, sorting out and selecting future academics. Research periods spent abroad can serve as a means of gaining marks of distinction in the symbolic contest for recognition and self-demarcation (Bourdieu, 1990, p. 110). With growing competition, these forms of international capital can make the small but significant difference between competitors who are endowed with the same titles and performance indicators (Schultheis, 2008, p. 49).

In this paper I have presented data that documents the gendering and stratifying effects of the institutionalisation of transnational academic mobility in academic career trajectories. Complex formations related to parenting and partnering, gender and social class as well as to embeddedness into the scientific community are resulting in inequalities in the accumulation of international cultural and social capital. Academics who are less able and willing to meet the requirements of the outlined ideal of an academic entrepreneur, -female and older academics, without academic family background, living in partnership, dual career constellations and with 
children, less frequently supported by mentors and without funding support - are at a disadvantage in the contests for recognition in the academic field.

Short biographical notes on all contributors

Leemann, Regula Julia, Professor for Educational Sociology, Research interests: education and social inequality/gender, trajectories and transitions in life course (in particular academic careers); vocational education and training.

\section{Notes}

1

http://www.bfs.admin.ch/bfs/portal/de/index/themen/15/06/key/ind1.indicator.10309.html?ope $\mathrm{n}=140 \# 140$ (access: 26th of December 2009).

2 Due to the tendency for women not to marry men of lower status (hypergamy), this variable captures an academic family background of scientists.

3 'Law' is omitted due to missing variance (cells without cases or perfect prediction).

$4 \quad$ Only relevant for women. Men did not mention being part of a mentoring programme.

5 'Project funding SNSF approved' is omitted due to missing variance (cells without cases or perfect prediction)

\section{References}

Ackers, L. (2004). Managing relationships in peripatetic careers: Scientific mobility in the European Union. Women's Studies International Forum, 27(3), 189201. doi: 10.1016/j.wsif.2004.03.001

Bekhradnia, B., \& Sastry, T. (2005). Migration of Academic Staff to and from the UK. London: Higher Education Policy Institute (HEPI). Retrieved from Higher Education Policy Institute: retrieved from: http://www.hepi.ac.uk/files/19BrainDrain.pdf

Bourdieu, P. (2004) [1986]. The forms of capital. In J. G. Richardson (Ed.), Handbook of Theory and Research for the Sociology of Education. Westport CT: Greenwood. Reprented 2004 in St. J. Ball (Ed.), The Routledge Falmer Reader in Sociology of Education (pp. 15-29). London: Taylor and Francis Group.

Bourdieu, P. (1990). Homo Academicus. Stanford, California: Stanford University Press.

Bourdieu, P., \& Passeron, J.-C. (1971 (1964)). Die Illusion der Chancengleichheit. Untersuchungen zur Soziologie des Bildungswesens am Beispiel Frankreich 
[Illusion of equity/equality. Studies on the Sociology of educational system. The Example of France]. Stuttgart: Klett.

Bronstein, P. (2001). Older Women in Academia: Contemporary History and Issues. Journal of Women's History, 12(4), 184-201. doi: 10.1353/jowh.2001.0004.

Bundesamt für Statistik (2009). Frauen und Männer im Bolognasystem. Indikatoren zu den geschlechtsspezifischen Unterschieden an den universitären Hochschulen [Women and men in the Bologna system. Indicators of gender differendes at Universities]. Neuchâtel: Bundesamt für Statistik. retrieved from:

http://www.bfs.admin.ch/bfs/portal/de/index/themen/15/22/publ.Document.11 8346.pdf

European Commission (2009). She Figures. Statistics and Indicators on Gender Equality in Science. Luxembourg: Publications Office of the European Union. doi: $10.2777 / 10329$

Gabaldon, T., Horta, H., Meyer, D.M. and Pereira-Leal, J.B. (2005). Career Paths and Mobility of Researchers in Europe. Göttingen: Culliver Verlag.

Kenway, J., \& Fahey, J. (2007). Policy Incitements to mobility: Some speculations and provocations. In R. Boden, R. Deem, D. Epstein, F. Rizvi \& S. Wright (Eds.), World Year Book of Education 2008: Geographies of Knowledge, Geometries of Power: Higher Education in the 21st Century (pp. 161-179). London: Routledge.

Krais, B. (2002). Academia and the Hierarchy of the Sexes. Higher Education Quarterly, 56(4), 407-418. Retrieved from:

http://www3.interscience.wiley.com/cgi-bin/fulltext/118955837/PDFSTART

Krüger, H., \& Levy, R. (2001). Linking Life Courses, Work, and the Family: Theorizing a not so Visible Nexus between Women and Men. Canadian Journal of Sociology, 26(2), 145-166. http://www.jstor.org/pss/3341676

Kulis, S., \& Sicotte, D. (2002). Women Scientists in Academia: Geographically Constrained to Big Cities, College Clusters, or the Coasts? Research in Higher Education, 43(1), 1-30. http://www.jstor.org/pss/40197249

Ledin, A., Bornmann, L., Gannon, F., \& Wallon, G. (2007). A persistent problem. Traditional gender roles hold back female scientists. EMBO reports, $8(11)$, 982-987. Retrieved from:

http://www.nature.com/embor/journal/v8/n11/full/7401109.html

Leemann, R.J \& Da Rin, S. (2010). Zum Verhältnis von Forschungsförderung, Laufbahn und Geschlecht-felspezifische und habituelle Bedingungen [Research funding, academic career, and gender - conditions of the field and the habitus], in R.J. Leemann \& Stutz, H. (Eds.), Forschungsförderung aus Geschlechterperspektive - Zugang, Erfolg und Wirkung [Research funding in 
a gender perspective - access, success and effects], Zürich: Rüegger.

(forthcoming).

Leemann, R. J., Boes, S., \& Da Rin, S. (2009). The 'Leaky Pipeline' in Switzerland:

What is causing women to drop out of academic research and careers at senior levels? Paper presented at the 2nd International Study Network on Higher Education (RESUP) Conference. Inequalities in Higher Education and Research. Retrieved from http://www.resup.u-

bordeaux2.fr/manifestations/colloque\%20international\%20Lausane\%202009/ Actes\%20T5.pdf

Leemann, R. J., Dubach, P., \& Boes, S. (2010). The Leaky Pipeline in the Swiss University System: Identifying Gender Barriers in Postgraduate Education and Networks Using Longitudinal Data. Swiss Journal of Sociology, 36. Special Issue on Longitudinal Analysis in Switzerland (forthcoming). http://www.sociojournal.ch/

Leemann, R. J., \& Stutz, H. (2008). Gender and Research Funding (GEFO). Final Report and Synthesis. Berne: Swiss National Science Foundation. Retrieved from http://www.snf.ch/SiteCollectionDocuments/wom_ber_gefo_synthesis_report _e.pdf

Marwell, G., Rosenfeld, R., \& Spilerman, S. (1979). Geographic Constraints on Women's Career in Academia. Science, 205, 1225-1231. doi:

10.1126/science. 1078446

McBrier, D. B. (2003). Gender and Career Dynamics within a Segmented Professional Labor Market: The Case of Law Academia. Social Forces, 81(4), 1201-1266. doi: 10.1353/sof.2003.0065

Moguérou, P. (2004). A double gender-family phenomenon in the international mobility of young researchers. Research Institute of Education (IREDU), University of Bourgogne. Retrieved from: http://129.3.20.41/eps/it/papers/0403/0403003.pdf

Müller-Jentsch, Daniel (2008). Die neue Zuwanderung. Die Schweiz zwischen BrainGain und Überfremdungsangst. [New Immigration. Switzerland between Brain-Gain and xenophobia]. Zürich: NZZ.

OECD (2008). Education at a glance. OECD indicators. Paris: OECD. Retrieved from: http://browse.oecdbookshop.org/oecd/pdfs/browseit/9608041E.PDF

Pongratz, H. J., \& Voß, G. G. (2003). From employee to ,entreployee': Towards a ,self-entrepreneurial' workforce? Concepts and Transformation, 8(3), 239254. doi: 10.1075/cat.8.3.04pon 
Romanin, S., \& Over, R. (1993). Australien Academics: Career Patterns, Work Roles, and Family Life-Cycle Commitments of men and Women. Higher Education, 26(4), 411-429. http://www.jstor.org/pss/3447681

Rosenfeld, R. A., \& Jones, J. A. (1987). Patterns and Effects of Geographic Mobility for Academic Women and Men. Journal of Higher Education, 59, 493-515. http://www.jstor.org/pss/1981784

Rusconi, A., \& Solga, H. (2007). Determinants of and obstacles to dual careers in Germany. Zeitschrift für Familienforschung, 19(3), 311-336. Retrieved from: http://www.zeitschrift-fuer-familienforschung.de/pdf/2007-3-rusconi.pdf

Schultheis, F. (2007). Der Lohn der Angst. Zur Normalisierung von Prekarität im grenzenlosen Kapitalismus. In P. Gazareth, A. Juhasz \& C. Magnin (Eds.), Neue soziale Ungleichheit in der Arbeitswelt [New forms of social inequalities in working environment]. (pp. 59-73). Konstanz: UVK Verlagsgesellschaft.

Schultheis, F. (2008). Pierre Bourdieus Konzeptualisierung von "Sozialkapital". Sozialkapital: Zur Genealogie des Gedankens. In W. Matiaske \& G. Grözinger (Eds.), Ökonomie und Gesellschaft. Sozialkapital: Eine (un)bequeme Kategorie [Economie and society. Social capital: a (dis)comfortable category]. (Vol. Jahrbuch 20, pp. 17-42). Marburg: Metropolis Verlag.

Shauman, K. A., \& Xie, Y. (1996). Geographic Mobility of Scientists: Sex Differences and Family Constraints. Demography, 33(4), 455-468. http://www.jstor.org/pss/2061780

Siemienska, R., \& Zimmer, A. (Eds.). (2007). Gendered Career Trajectories in Academia in Cross-National Perspective. Warsaw: Wydawnictwo Naukowe Scholar.

Teevan, J. J., Pepper, S., \& Pellizzari, J. R. (1992). Academic Employment Decisions and Gender. Research in Higher Education, 33(2), 141-160. http://www.springerlink.com/content/hm75849vlw656h28/

van der Hijden, P. (2009). European Union Initiatives to Enhance the Attractiveness of the Research Profession in Europe. European Educational Research Journal, 8:550-554. doi: 10.2304/eerj.2009.8.4.550 